Studies in Continuing Education, Vol. 22, No. 1, 2000

\title{
Between Common and College Knowledge: exploring the boundaries between adult and higher education
}

\author{
Mark Murphy \& Ted Fleming \\ National University of Ireland Maynooth, Ireland
}

ABSTRACT The debate about access to higher education in Ireland has been linked to the debate about educational equality and socio-economic disadvantage. Most of the discussion so far has centred on mechanisms for gaining entry to higher education institutionsestablishing access and foundation courses, increasing numbers of non-traditional entrants and generating modular and credit-based programs. The findings from research undertaken at both the National University of Ireland at Maynooth and Dublin, explored the experience of mature students returning to university. The findings indicate that questions of equality and disadvantage in the university are not only concerned with access, but also with accessibility - what happens to mature students when they arrive in college. This paper goes on to reconstruct the conflict between the common-sense knowledge of the returning student and the college knowledge of the academy in a way that identifies a collaborative and democratic discourse as providing a way of transcending the false dichotomies of common versus college knowledge. Habermas' ideal speech situation and theory of communicative action are identified as providing a framework for this task. In relying on this set of ideas the case is made for linking higher education and adult education with the quest for democracy and a more just and caring world.

\section{Introduction}

The issue of access for mature students has come to the fore in Irish higher education. Several publications have highlighted and explored the policy and practical aspects of access to higher education (Fleming \& Murphy, 1997; Morris, 1997; Fleming, Collins \& Coolahan, 1999; Inglis \& Murphy, 1999; Murphy \& Inglis, 2000). The government report on the future of higher education (Steering Committee on the Future Development of Higher Education, 1995) proposed that mature students as a proportion of full-time entrants should increase to $20 \%$ of total entrants by the year 2015. The Government White Paper on education (Department of Education, 1995) emphasised the importance of achieving greater equality in education. The Universities Act (1997, paragraph 12(j)) defined one objective of the university as "to facilitate lifelong learning through the provision of adult and continuing education". More recently and more significantly, the Irish government 
produced a Green Paper on adult education (Department of Education and Science, 1998), which consolidates some of the issues put forward by previous reports and government documents.

The key issue in this Irish debate is access-opening the system of higher education so that more adults can avail of what is essentially an elitist system of education for the children of the middle classes. Access to higher education is viewed as a significant factor in reducing inequality and disadvantage. Clancy echoes many of the recommendations of other reports, when he states that second-chance education "must not be seen as a luxury which we can attend to when the demographic pressure has passed at the end of this decade. Social justice and economic considerations dictate that it be seen as a current priority" (1995, p. 115).

This interest in issues relating to access is a welcome addition to the Irish debate on education and inequality. We argue in this paper that this debate does not go far enough. We argue that, if social and justice considerations are taken seriously, then the higher education institutions themselves need to be examined more closely, particularly when it comes to the production of knowledge.

The purpose of this paper is to illustrate how issues of access to higher education, and as a consequence, access to power, status and privilege, are as much to do with the knowledge produced in the academy and its accessibility, as they are to do with mechanisms for increasing the number of mature students in third level. This issue opens up an array of broader questions concerning the relationship between power and knowledge. This paper attempts to identify how relations of power are manifested in the relationship between the adult learner and the university, and how this in turn represents a conflict of knowledge interests between adult and higher education. If we take seriously the notion that the university provides space for critical reflection and that its role is to cultivate such reflection, then the university must take seriously the need to transform the knowledge gap between adults and academia.

\section{Access and Accessibility in Higher Education}

Debates about higher education and adults have tended to focus on issues of access, to the detriment of accessibility. The difference between these two approaches is outlined in the following quote on English higher education:

The first approach tends to dwell on mechanisms of access-on ways for making possible the entry into higher education of so-called "non-traditional" students. ... The second type of approach ... aims, above all else, at increasing the general accessibility of the higher education system as a whole; at identifying, and overcoming the multifarious factors which make it remote, or unattractive, to the majority of the English population. (Wright, 1989, p. 99)

This discussion, when examined more closely, really focuses on the kind of boundaries existing between adult and higher education institutions. It is an issue of access into higher education not only for adults, but also for adult education. This 
is the approach put forward by those involved in the British access movement, which has moved on from focusing on mechanisms of access such as outreach programs and accreditation of prior learning, to examining how higher education is equipped to cope with adult learners who successfully enter the institutions (Fulton, 1989; Parry \& Wake, 1990; Schuller, 1991; Duke, 1997).

Those involved in the access movement often see higher education as maintaining rather than reducing social inequality. They argue that universities function to stifle and inhibit the participation of adults. The accessibility movement is founded on the principle of making the university more "adult friendly" (NIACE, 1993; Merrill, 1999). There is a need

for a system that recognises the distinctive experiences adults bring to their learning. ... Provision for adult learners needs to take account of the experience adults bring to their learning, the complexity of their objectives, the discontinuity of their participation, and the financial complexity of their lives. (Tuckett, 1990, p. 127)

There is a subsequent call for the academy to adopt a "learner-centred" approacha traditional adult education philosophy. "If an adult higher education implies a learner, rather than subject-centred curriculum, tutoring and guidance must be central functions, rather than emergency services added at the margins to cope with problems" (McNair, 1998, p. 171).

Others have highlighted the indifference higher education institutions exhibit in relation to the experience-based knowledge adult learners bring with them:

Low self-esteem and the sense that one does not "really belong here" can quickly be brought to the surface by the attitude of a tutor who regards prior experience as of little value, or by someone who briskly or impatiently urges someone to speak up. Another may feel undermined by an encounter with a teacher who, like a woman's husband, quietly thinks that the emphasis women might place on the interpretation of connections within the whole, and on interrelationships, is slightly suspect on a science course. Her interventions, her attempts to make sense of the subject within her world view, may continually remain quietly and politely unrecognized and kept invisible until, without watering, attempts to speak wither and die. (Weil, 1989, pp. 137-138)

Here, adult educators are making a connection between power and knowledge in the institution. They are not the only group to make such a connection. Other theories have critiqued the nature of knowledge generated and transmitted in the academy, and the role of this knowledge in society. Academic knowledge is problematised from various directions - for monopolising the truth, for lacking relevance, for losing touch with the "real" world, for excluding the voices of those not traditionally a part of the student population, and for reproducing an unequal social order. Marxists, feminists and post-modernists have provided critiques of higher education based on its epistemology. The emphasis placed on objectivity and factual-based empirical 
evidence has been the centre of much debate since the 1960s. While Bowles and Gintis (1976) and Giroux (1981) provided critiques of higher education as a reproducer of material inequality, others from a Marxist orientation focused on the production of knowledge within the institution. In the 1970s, a movement known at the time as the "new" sociology of knowledge came to prominence led by Young (1971). Young and his associates were concerned with what counted as valid and important knowledge. They viewed knowledge in higher education as already defined by those in power and positions of authority. They posit their own knowledge as superior to others, and in this way maintain power and privilege.

As part of Young's critique, he posited a relative theory of knowledge, a theory that has since been taken up in the work of post-modernists. Post-modern theories have provided the basis for critiques of the foundations of academic disciplines, whether in the humanities or the natural sciences. What post-modernism, in its various guises, has attempted to do, is to historicise the foundations of academia, to show that reason, truth and objectivity are only products of historically contested social relations. In this way, truth becomes a game in which different contestants compete for the privilege of positioning their knowledge as the truth. According to Foucault (1980), knowledge is indissociable from regimes of powerthe source of his famous power/knowledge relationship. Lyotard's work, the PostModern Condition (subtitled "A Report on Knowledge") (1984), was commissioned as a study of the status of higher education in Quebec. He posits a conflict between two types of knowledge-scientific and narrative. Scientific stands for objectivity, truth and reason, whereas narrative knowledge is the product of subjective, anecdotal ways of knowing. Scientific knowledge, according to Lyotard, wishes to see itself as the one true knowledge. However:

... scientific knowledge cannot know and make known that it is the true knowledge, without resorting to the other, narrative, kind of knowledge, which from its point of view is no knowledge at all. Without such recourse it would be in a position of presupposing its own validity and would be stooping to what it condemns; begging the question, proceeding on prejudice. (Lyotard, 1984, p. 29)

This analysis has echoes in the feminist critique put forward by Women's Ways Of Knowing (Belenky, Clinchy, Goldberger \& Tarule, 1986). The authors argued that ways of knowing identified historically as feminine (intuitive or feeling-based knowing, empathy-like procedural knowing) have been devalued and discouraged in institutions of higher learning in favour of propositional knowledge and abstract, meta modes of knowing, particularly those that valorise objective impartial knowledge (Goldberger, Tarule, Clinchy \& Belenky, 1996, p. 9). Academic knowledge is viewed as historically male constructed, but at the same time universalised to include female knowledge under its banner. The positioning of reasoning over emotion, for instance, is an example of how higher education institutions have tended to devalue "female" knowledge. 


\section{Adult Education, Knowledge and Higher Education}

Lyotard talks about the devaluing of narrative knowledge, even though it provides a necessary link to more scientific, objective forms of knowledge. Adult educators have provided a similar argument. Here, academia has been criticised for not recognising and valuing the significance of experiential knowledge, a form of narrative knowledge. ${ }^{1}$ The world of subjectivity forms the basis of experiential, or common-sense, knowledge, and as such, tends to conflict with the focus on the general and the abstract in academia. The kind of knowledge gained by adults from their experiences in the world of work, family and travel, is the mainstay of adult education. Indeed, adult education tends to look towards more subjective, individual and psychological concepts as a basis for its practice. Lawson, for instance, views subjective theories of the self as a good starting point for a theory of adult education epistemology:

An individualistic theory is provided in the tradition of Descartes, for whom the irreducible "I" that thinks is the source of all knowledge, because the existence of the self is the one thing no-one can doubt. The subjective self thinks and has experience, and being able to have sense experiences is the basis of rational empiricism. Experience, rationally ordered, is the source of what we know. (Lawson, 1991, p. 282)

This privileging of the self in adult education, combined with a post-modern spin on the nature of knowledge and the celebration of difference, is the starting point for a model of adult education in conflict with the tenets of higher education-reason, truth and objectivity. Adult education, in some quarters, has taken an oppositional stance to the academy, viewed as an institution that does not value the experiences of the adult learner. Where the academy validates objective knowledge, adult education, particularly in its liberal and community education formats, celebrates the subjective and the experiential. The world of experience becomes the central issue and basis upon which learning takes place, rather than the world of ideas.

We wanted to explore the kinds of boundaries that exist within the institutions themselves. What barriers to knowledge are manifested in the experiences of adult learners? It is the type of real or imagined boundaries felt by adults that, in many ways, constitute the most difficult and intransigent barriers to creating an adult higher education of lifelong learners.

\section{Mature Students in Irish Higher Education: negotiation and resistance}

Data examined below are compiled from two studies. One was funded by the Department of Social Welfare and carried out in the National University of Ireland, Maynooth, the other by the Higher Education Authority, and took place in University College Dublin (Fleming \& Murphy, 1997; Inglis \& Murphy, 1999). ${ }^{2}$ Although these studies were carried out in different universities, a similar theme emerged regarding the mature student experience and accessibility in higher education. The general question asked in both of these studies was: "What were the most significant factors involved in the success of students?" We found that financial issues, relation- 
ships with partners and other external commitments, the support they received at college, and the type of access route they took, all had a bearing on their success.

It became clear that, while these issues were important and presented difficulties for students, the learning process also presented students with a major barrier to achieving a degree. What we found intriguing was how mature students attempted to meet their own learning needs and the requirements of the college. What exists between the individual mature student, with their experiential knowledge, and the college, with its highly structured, abstract theoretical knowledge, is a latent conflict that manifests itself in various ways. In particular the conflict arises in the process of writing essays and examinations.

\section{Essay Writing}

Essay writing can cause significant problems for mature students, particularly for those who have had no previous experience of higher education. Their only real experience of writing was at school. Many can, at best, just about remember the kinds of rules that applied then. The university has different sets of rules when it comes to the structure and content of essays. Much of the anxiety mature students experienced was caused by not knowing what was expected of them. The traditional academic structure of an essay with an emphasis on description and analysis is known to those who have worked in the academic field for a longer time. Liam was made aware of what was required of him when he handed in his first essay:

My history tutor in first year, she was excellent, and when she handed my essay back, and when I read it, I couldn't believe I had written it, it was like a sixteen year olds. I had a bit of a clash with what I felt I should write. I think it was a lack of confidence in my ability to write. I kind of stopped myself writing. ... It was basically a narrative with no references, no quotations. I had given my own interpretation. ... I suppose that had to do with my own view of education being participatory.

"A nightmare" is how Julie described the experience of her first essay. In the following quote, she provides a stark portrayal of the kinds of problems mature students face when their understanding of what is expected of them does not coincide with that of their lecturers and tutors. She did not do as well as she hoped in her first essay:

I was at a talk and there was a woman talking, and she said she cried over an essay, and I laughed and thought, cry over an essay? I could never make it to the bridge, tears, God, and I thought "cop yourself on" and I was terrified someone would see me ... and there were road workers, and seriously I nearly died. Got to a phone anyway ... and I said get [sister's names] to ring me. Nobody rang me until it was ten o'clock at night and I was going round in floods of tears getting the dinner. ... Half ten at night I was still crying, my younger sister rang, and I answered the phone and told her I hadn't stopped crying since half eleven that morning, and she 
went, what? And I said I'm never going back there again. The amount of work I put in to the essay, and she (the lecturer) just said to me, you just passed it, and it was like putting a knife in my back, and she went, oh for god's sake, and she turned around and said, that's the thing about mature students. And I went what do you mean? And she went, you take everything to heart ... it was a major shock just passing it, 'cause I had done a lot of work ... I went up to the lecturer and said to her, I can't do this (the essay), and she said just go home and write from the heart, so I went home and wrote this flowery essay ...

Margaret, a mature student from UCD, also had the same problem, and was required to go through a steep learning curve to produce an essay considered adequate by her department:

I think especially with writing essays at the beginning too, you don't know what is required, you kill yourself doing it, but you mightn't be on the point. And it must be a learning process. I suppose you don't always get it right anyway, first time around or anything, subsequent times, but maybe by second year you have a better idea about how to go about it.

For all their effort and obvious enthusiasm, these mature students had not yet learned that what was required was a more depersonalised content and style. Achieving this brought better essay marks. Mary, an arts student from Maynooth, also had trouble with the essays, but she did much better, precisely because she depersonalised the essay-writing process. As she put it, the first essay:

... nearly killed me, I got 68 but it nearly killed me doing it cause I never did an essay, it was a different thing. I mean I don't know about analysing, from all I knew, even on the diploma course, that was just facts, facts, facts. It took a lot, I had to twist my whole mind around, but I did very well in it.

This "twisting the mind around" to suit the wishes of the academic faculty is a major factor influencing their success or failure. This intellectual game-playing was also important when it came to the techniques necessary for effective study.

\section{Study-skills}

Students must learn how to study and quickly develop learning skills if they are to succeed. Tom, when asked why he felt people failed at college, had this to say:

I think they failed to grasp ... they missed what it was, it's a very subtle thing. I know a few people who failed, who you know were just off centre, they weren't grasping, they were working very hard, but they weren't working at what they should have been, but they weren't concentrating. ... They should have been doing half an hour instead of two hours. The same people tend to grasp the wrong idea, the lecturer is saying something, and he's saying it in black and white, I want you to do the 
following, and he'd say it that slow, and they don't pick it up, and I think it's concentration.

What is this "very subtle thing" that Tom is talking about? John provided the following explanation:

The one insight that I had was that you can't do everything, and there's certain areas that you zone in on, there are certain areas that are more important.... It was something that one of the lecturers said. Someone said, don't read whole books, read chapters.

Jim also learnt in his first year at college that "there was no need to take down everything the lecturer says". Irene agreed, adding that what you take down during lectures is fundamental to success. She received $75 \%$ for her first essay by "making information her own". She got to this stage:

... first of all, by a desire to get through first year. I knew that I had to do more than just give back the facts if I was going to get good grades.... I (learnt this) mostly from what the lecturers were saying. To get the good marks you have got to give a critique. I just knew that it would be enough to get an honour, but not a first class honour.

The lack of examination practice meant that mature students were at a disadvantage when compared to 17- and 18-year-old students who only recently completed their Leaving Certificate. One student from UCD, Fiona, could not comprehend the standards set for exams because it was so long since her last exam:

I think it's the fact that you haven't just done your Leaving Certificate, so you don't know how you rate compared to the other students. You don't know what the standard is in exams, so you actually don't know when to do an exam whether you've done well or badly, because you have no standard to judge it by. I know certainly after first year, I lay awake at night, thinking, going over the paper, well I failed that one, and I failed that one. And I actually hadn't failed any of them, but I knew I had failed them.

Ruth, another UCD student, also had a significant problem with the academic culture of the university. She had worked as an occupational therapist prior to coming to college and, although she liked her subjects, she found the course work overbearing and confusing at times:

It was good, but it was stressful, and certainly for me, I just didn't know at any stage, particularly in the first year, what level I was actually at, what was expected of me, and then what level I was functioning at. So first year exams were a complete nightmare.... I had absolutely no idea whether I was functioning on pass level or anything.

In many ways, what these mature students are doing here is learning the "tricks of the trade", learning what we call college knowledge (Fleming \& Murphy, 1997). The ability of students to learn this knowledge is a determining factor in mature students' 
success. Trish, in her twenties, provided a good example of this, when she explained the difference between her and older mature students:

We were asked to study a particular diagram in class, and learn it off, and this older friend of mine was saying, that arrow shouldn't be there, and I was saying, it's there so just learn it that way, and she was going, but why is it there and I said, I don't know and don't care, just learn it so you can regurgitate it in the exams and get marks for it.... She wanted to know the mechanisms and the nitty gritty of it, which would need a bit more knowledge than anyone would have in second year. ... It wasn't necessary to know the nitty gritty in second year, and by asking why, she was actually dragging herself deeper into the mire.

So Trish felt that she could "run with the hare and dash with the hounds". It is very clear that, for Trish, the dissonance between her own learner identity and the college identity was diminished. It was a very conscious process for her. The only way she could reduce the dissonance and get through college was to give the college what they wanted-college knowledge. She put it most clearly when she named two kinds of learning:

Yeah, one is the monkey business and the other is the research.... In departments, each person is looking for something different and you can do the monkey business for one lecturer and the research for another. ... It's a question of finding the dynamic equilibrium between the two of them ... it's about passing your exams as a means to an end. I knew what was necessary to pass this time.

In contrast, Paul did not learn some of these tricks of the trade and did not learn how to play the game properly. $\mathrm{He}$, as a result, had to repeat first year because of the way he approached the writing of his exam questions. As he explains:

... the head of [names Department] couldn't understand why I failed, and they were really worried. They thought they had got the marks wrong or something. They said I had attended the lectures. I got these great results in my essays, and then they looked at my exam papers and they found that I was averaging a page and a half per answer, and it's just not on, you know.... I learnt to give lot longer answers basically (laughs). Skill in the economy of space.

The learning of skills such as the one Paul described are one of the main academic experiences of mature students at college. This process of skills learning, however, is really a manifestation of the underlying latent conflict between these mature learners and the learned of the college. The process through which mature students go in attaining these skills is one of constant compromise with the demands of the college, of a giving in to an authority that will not accept their experiential knowledge. It is important to point out in this instance that the college rarely compromises. The students themselves are frequently on the losing end, and the 
process of playing the game is, for many students, the only realistic way of losing less.

\section{Discussion: exploring the boundaries between adult and higher education}

The analysis presented here is limited in the sense that it is based on the findings of studies carried out in two Irish universities. These universities are not necessarily representative of Irish universities or universities in general. Having said that, the mature students included in the studies were chosen at random, and more significantly, the majority of them had similar, unprompted, narratives to communicate. There are two interlinked issues at the heart of these narratives that define the broader parameters of the access debate-the form of learning offered by the university; and the type of knowledge defined as valid and useful. It became clear to adult learners that their subjective knowledge, accumulated over a lifetime of working and raising families, is ignored by the university as having little to do with academia.

The disjuncture experienced by mature students between their perceptions of what was required and what the institution demands of them, forms the basis of a latent conflict. This conflict is worked out on two grounds:

- between two different forms of knowledge, what we call "common" or subjective knowledge, and "college" or objective academic knowledge;

- between two different approaches to learning, the experiential learning approach, of course the mainstay of adult education, and the academic approach to learning, the one based on the exploration of theory and ideas.

These two areas of disjuncture constitute a conflict of interests between adult and higher education. These interconnected battlegrounds provide the real barriers to access for adult learners.

It is interesting to point out that many of the adults we talked to had taken preparatory adult education courses. Many times adult learners find the learner-centred and experiential approaches of access courses at odds with that put forward in university. This issue is highlighted by Melling and Stanton (1990, p. 144):

If learning programmes on preparatory or access courses are increasingly tailor-made to suit the learning needs of individuals, then this is likely to increase the degree of curriculum discontinuity which can already exist between such courses and those in higher education itself. There is some evidence that learners who have prospered on specially designed access courses find the transition to higher education difficult not because of any lack of ability but because of the inflexibility and unresponsiveness of teaching methods in much of higher education.

West (1996) found that this results in a fragmentation of the student in the experience of returning to college. The self becomes fragmented into private (being a partner or parent) and public spheres (the student). The fragmentation involves a separating of experiential ways of knowing that are personal, subjective and 
emotional, from academic ways of knowing that are objective and abstract (West, 1996, p. ix). Students in his study wondered why academic and personal knowledge could not be merged (West, 1996, p. 203).

Bruffee (1993) describes students arriving at university as already functioning members of a knowledge community. They are fluent in its language and confirmed in its experiential and common-sense basis. Going to college, he says, involves becoming a member of a different knowledge community. Thus the task of the university is to reacculturate students into a new language community by teaching the language that constitutes that community (Bruffee, 1993, p. 17). In highlighting the difference between the knowledge base of the arriving student and the need to become a member of another community, Bruffee is suggesting a form of resocialisation of the student. It may be appropriate for children to be inducted into the culture or resocialised but adults are capable of taking a more critical stance toward culture and society. Deculturing might be a more interesting idea rather than reacculturation; desocialisation rather than resocialisation.

\section{Beyond Common and College Knowledge}

In the following quote, Weil identifies how short-sighted and myopic present debates are regarding adult provision, and their reluctance to come to terms with some fundamental issues that affect the relationship between adult and higher education:

Adult learners do not bring their experience with them into education; they are their experience (Knowles, 1978). But the answers to the real complexities and challenges of this idea do not seem to lie simply in modular programmes, access courses, distance- or open-learning initiatives, experiential learning or andragogy. They lie in much finer nuances of expressing respect, concern and care for individuals, and in giving priority to the need for adults to build upon and make sense of their experiences within the context of their own and others" "life worlds". (Weil, 1989, p. 142)

This conflict rests on two very different educational philosophies, which encompass two juxtaposed notions of educational process and content: One, the adult education philosophy — with a student-centred, experientially based learning process, with an elevation of subjective knowledge as the generator of other knowledges; and the higher education philosophy, with its subject-centred processes and focus on objective factual data.

The real question behind any talk of accessibility concerns the control and definition of knowledge. Knowledge, and the definitions of what counts as useful and valid knowledge, constitute the main boundary between adult and higher education:

The expansion of secondary and higher education throughout the twentieth century has not succeeded in building a well-educated citizenry capable of participating effectively in the political processes which shape their lives. 
There is a tightening link between knowledge, power and the impersonal structures of a global economy. In the information society new fracture lines of social inequality are built on differential access to the means of communication, learning and knowledge. (Williamson \& Coffield, 1997, p. 8)

It is as if a script has been written where two sectors of education ensured they would be diametrically opposed-one taking the subjective and experiential approach to knowledge and as a consequence learning, and the other the objective and factual-based approach. We are reminded by Belenky et al. (1986, p. 124) that:

[I]n the institutions of higher learning most of the women attended, the subjective voice was largely ignored; feelings and intuitions were banished to the realm of personal and private. It was the public, rational, analytical voice that received the institutions' tutelage, respect, and reward. Most of these women profited from the tutelage, respect, and rewards, and most were grateful to their colleges for nurturing their analytical powers. In acquiring the skills of separated knowing, women in this position did, indeed, transcend the stereotypes of women as creatures ruled by instinct and emotion, incapable of reason; but they also adopted a stereotyped view of reason as detached from feeling and removed from everyday experience.

From a more radical tradition in adult education, Paulo Freire, in discussions with Myles Horton (Bell, Gaventa \& Peters, 1990, p. 97), asserted that people have the right to participate in producing new knowledge. The people's knowledge he calls practical knowledge and the knowledge the teacher brings to the discussion he calls theoretical knowledge. The task for the teacher is to better understand theoretically what is happening in the people's practice. This he (Bell et al., 1990, p. 101) describes as:

... going beyond the common sense of the people, with the people. My quest is not to go alone but to go with the people. Then having a certain scientific understanding of how the structures of society work, I can go beyond the common-sense understanding of how the society works - not to stay at this level but, starting from this, to go beyond. Theory does that.

Freire is not claiming that educators do not have knowledge, no more than he is claiming that students do not have knowledge. When students arrive they bring with them their hopes, despair, expectations, knowledge, which they got by living. Freire puts it this way:

They do not arrive empty. They arrive full of things ... they bring with them their knowledge at the level of common sense, and they have the right to go beyond this level of knowledge... This is a right that the people have, and I call it the right to know better what they already know. Knowing better means precisely going beyond the common sense in order to discover the reason for the facts. (Bell et al., 1990, p. 157) 
In attempting to move the discussion forward and transcend the false dichotomies of subjective knowledge and academic knowledge, the work of Jürgen Habermas offers a provocative and radical possibility. He outlines a way in which neither objective nor subjective; neither experiential nor theoretical knowledge are given supremacy. By transcending these dichotomies, neither students nor the academy will be triumphant in the playing out of competing knowledge claims. Both will move to a new positioning, toward what Habermas calls the ideal speech situation. The ideal speech situation seeks to "institutionalize discourse or critique systematically distorted communication" (McCarthy, 1975, p. xvii).

Habermas has emphasised for some time the crucial role public discussion and debate plays in the formation of the needs, interests and aspirations of individuals (Habermas, 1989). Discussion aimed at resolving practical disputes through consensus is at the core of Habermas' critique of capitalist modernisation. The public sphere or public discussion has been reduced by the activities of politicians, advertisers, public relations and the media in general. This theme has emerged again in his more recent work (Habermas, 1996), where he links the concept of a public sphere with that of civil society to provide an account of how control can be exercised over markets and bureaucracies. The quality of democracy ultimately depends not on politicians but on the existence of this public sphere, on people's intelligent involvement in politics and on organisations and associations that help form opinion through discourse. The conviction that free, open, public discussion has a transformative function is central to Habermas' thinking. In adult education this is the same discourse that Mezirow asserts is the process required for engaging in transformative learning (Mezirow, 1994).

This kind of discussion, the ideal speech situation or communicative action, has within it the possibility of transforming the relationship between the knowledge of the academy and that of the students. But what kind of discussion is Habermas talking about? He is talking about discussion aimed at resolving practical disagreements and involves the implicit commitment to a set of rules. These rules of discussion involve the equal rights of all concerned; an obligation to provide reasons for challenging what others assert; having appropriate evidence in support of arguments; and the examining of alternative and other people's perspectives (Habermas, 1990).

In this never-realised ideal speech situation validity claims, tacitly agreed in normal conversation, become subject to explicit critique and debate. Disputes about what may be the truth are resolved through argumentation and agreement is reached solely on the basis of the better argument. In this discourse we anticipate a form of life characterised by unconstrained and undistorted intersubjectivity (McCarthy, 1978, p. 325). Discourse requires freedom and justice-freedom to reach agreement on the basis of the better argument alone and justice based on mutual respect. This discourse is both rational and emancipatory in its intention because the process of reaching agreement is accompanied by a revealing of the ideological, coercive and non-democratic structures that hinder a genuinely democratic process (Collins, 1991, p. 12).

This ideal speech situation, though never realised, is anticipated in all communi- 
cations. The conditions for fully participating in discourse and in adult learning are the same. It is assumed that all participants:

- have accurate and complete information

- are free from coercion and distorting self-deception

- are open to alternative points of view-empathic and caring about how others think and feel

- are able to weigh evidence and assess arguments objectively

- are able to become aware of the context of ideas and critically reflective of assumptions, including their own

- have equal opportunity to participate in the various roles of discourse

- are willing to accept a resulting best judgement as a test of validity until new perspectives, evidence or arguments are encountered and subsequently validated through discourse as yielding a better judgement (Mezirow, 1998, p. 3).

This process of engaging in discourse free from domination is well established as a core principle of transformative and radical adult education. This respectful, critical and thoughtful group learning experience is what Freire proposes as dialogic interaction (Collins, 1991, p. 2). Harkin has also argued that this is a useful defence against the post-modernist's difficulty of "bridging the gap between persons" (Harkin, 1998, p. 429). Contra Lyotard (1984, p. 17), communication need not be war.

\section{Conclusion}

On this basis we suggest that an academic community of enquiry ought also be engaged in a discourse free from domination, in a respectful, critical and collaborative process. The issue here is not to valorise either experiential or objective knowledge. The knowledge generated in such discourse is neither subjective nor objective but emancipatory and transformative. In this way it becomes possible to link ideas from adult education (dialogic interaction, transformative learning) with the interest of both students and the university in freedom, equality, tolerance, critical enquiry and valuing of rationality. The learning community thus created is that described or worked for by radical adult education and is precisely what is required for transformative learning. The re-creation of the life world, the development of civil society, the emergence of a truly democratic system and society are all connected in this vision.

The role of the radical adult educator and the university is therefore one of encouraging and creating situations, and classrooms that encourage the fullest participation in discourse, allowing adults to critically assess the validity of their ways of making meaning and explore more open perspectives. Too much adult and higher education has been about work, skills, instrumental learning and how to do things. It has been preoccupied with defining learning tasks and outcomes, behavioural objectives and measurable competence. Too much has been made about the state, the economy and workplace training. A different kind of learning is proposed. It involves a critical reflection on assumptions that underpin our beliefs, 
a discourse to justify what we believe and taking action on the basis of the new agreed understandings. What we propose is a coming together of adult and higher education - of process and content, of subjective and objective knowledge, of experience and ideas. In essence what this other kind of learning requires is the coming together of theory and practice-of common and college knowledge.

Address for correspondence: Ted Fleming, Centre for Adult and Community Education, National University of Ireland Maynooth, Maynooth, Co. Kildare, Ireland. E-mail: ted.fleming@may.ie

\section{Notes}

1 Experiential knowledge constitutes a large and significant sub-section of adult education theory. It is important to acknowledge that experiential knowledge is not generally treated in adult education debates as a simple notion bereft of ideological and political assumptions, but rather as a complex concept that can have several dimensions depending on the epistemology or paradigm in use. For instance, Weil and McGill (1989) talk about the four "villages" of experiential learning, while Boud (1989) has outlined four main competing traditions in experiential learning. Others, such as Johnston and Usher (1997) have approached the debate surrounding experiential knowledge from a post-modern perspective.

2 Both studies used a combination of qualitative and quantitative methods in the research process. Combining the two studies, 226 mature full-time undergraduate students provided information for the study, an aggregate return of $57 \%$ of the total. The scope of the reports was broader than the research presented indicates, covering as they did other issues such as access, finance, relationships and external commitments. The UCD report also looked at other populations of mature students, those who graduated for instance. Presented here are the findings from the qualitative research that had implications for the debate on accessibility. Individual semi-structured interviews with 20 full-time mature students were carried out at NUI, Maynooth, while two focus groups comprising the same number were carried out at UCD. These were randomly chosen from the data gathered in the questionnaires.

\section{References}

Belenky, B.M., Clinchy, B.M., Goldberger, N.R. \& TARUle, J.M. (1986). Women's ways of knowing: The development of self, voice and mind. New York: Basic Books.

Bell, B., Gaventa, J. \& Peters, J. (1990). We make the road by walking: Conversations on education and social change-Myles Horton and Paulo Freire. Philadelphia: Temple University Press.

Boud, D. (1989). Some competing traditions in experiential learning. In S. WeIL \& I. MCGILL (Eds.), Making sense of experiential learning: Diversity in theory and practice (pp. 38-50). Milton Keynes: Society for Research into Higher Education and Open University Press.

Bowles, S. \& GinTis, H. (1976). Schooling and capitalist America: Educational reform and the contradictions of economic life. London: Routledge and Kegan Paul.

BRUFFEE, K. (1993). Collaborative learning: Higher education, interdependence and the authority of knowledge. Baltimore: Johns Hopkins University Press.

Clancy, P. (1995). Access courses as a way towards addressing socio-economic disparities in participation in higher education. In HIGHER EDUCATION AUTHORITY, Access courses for higher education (pp. 95-115). Proceedings of HEA Seminar, Mary Immaculate College, Limerick. Dublin: Higher Education Authority. 
Collins, M. (1991). Adult education as vocation: A critical role for the adult educator. London: Routledge.

Department of Education. (1995). Charting our education future. Government White Paper on Education. Dublin: Stationery Office.

DePartMENT OF EDUCATION AND SCIENCE. (1998). Adult education in an era of lifelong learning. Government Green Paper on Adult Education. Dublin: Stationery Office.

Duke, C. (1997). Towards a lifelong curriculum. In F. Coffield \& B. Williamson (Eds.), Repositioning higher education (pp. 57-73). Milton Keynes: Society for Research into Higher Education and Open University Press.

Fleming, T., Collins, T. \& Coolahan, J. (Eds.). (1999). Higher education: The challenge of lifelong learning. Maynooth: National University of Ireland Centre for Educational Policy Studies.

Fleming, T. \& Murphy, M. (1997). College knowledge: Power, policy and the mature student experience at university. Maynooth: MACE.

Foucault, M. (1980). Power/knowledge: Selected interviews and other writings, 1972-1977. New York: Pantheon.

Fulton, O. (Ed.). (1989). Access and institutional change. Milton Keynes: Society for Research into Higher Education and Open University Press.

Giroux, H. (1981). Ideology, culture and the process of schooling. London: Falmer Press.

Goldberger, N.R., Tarule, J.M., Clinchy, B. \& Belenky, M.F. (1996). Knowledge, difference and power: Essays inspired by "Women's ways of knowing”. New York: Basic Books.

HABERMAS, J. (1989). The structural transformation of the public sphere: An enquiry into a category of bourgeois society. Cambridge, MA: MIT Press.

HABERMAS, J. (1990). Moral consciousness and communicative action. Cambridge, MA: MIT Press.

HABermas, J. (1996). Between facts and norms: Contributions to a discourse theory of law and democracy. Cambridge: Polity Press.

HARKIN, J. (1998). In defence of the modernist project in education. British fournal of Educational Studies, 46(4), 428-439.

INGLIS, T. \& MURPHY, M. (1999). No room for adults? The experience of mature students in University College Dublin. Dublin: UCD Social Science Research Centre and Adult Education Office.

Johnston, R. \& UsheR, R. (1997). Re-theorising experience: Adult learning in contemporary social practices. Studies in the Education of Adults, 29(2), 137-153.

KNowles, M. (1978). The adult learner: A neglected species. Houston, TX: Gulf Publishing.

Lawson, K.H. (1991). Philosophical concepts and values on adult education. Milton Keynes: Open University Press.

LyotaRD, J.-F. (1984). The post-modern condition: A report on knowledge. Manchester: Manchester University Press.

McCarthy, T. (1975). Preface to legitimisation crisis. Boston: Beacon Press.

MCCARTHY, T. (1978). The critical theory of Fürgen Habermas. Cambridge, MA: MIT Press.

MCNAIR, S. (1998). The invisible majority: Adult learners in English higher education. Higher Education Quarterly, 52(2), 162-178.

Melling, G. \& Stanton, G. (1990). Access to and through further education. In G. ParRy \& C. WAKE (Eds.), Access and alternative futures for higher education (pp. 134-145). London: Hodder and Stoughton.

MERRILL, B. (1999). The adult learner-Developments and research in the United Kingdom: Contextualising access in the UK. In T. Fleming, T. Collins \& J. Coolahan (Eds.), Higher education: The challenge of lifelong learning (pp. 45-54). Maynooth: National University of Ireland Centre for Educational Policy Studies.

Mezirow, J. (1994). Understanding transformation theory. Adult Education Quarterly, 44(4), $222-232$.

Mezirow, J. (1998). Transformation theory of adult learning-Core propositions. Paper presented at the First National Conference on Transformative Learning, Columbia University, New York, p. 3. 
Morris, R. (Ed.). (1997). Mature students in higher education. Proceedings of Conference at Athlone Regional Technical College, 1996. Cork: Higher Education Equality Unit.

Murphy, M. \& INGLIs, T. (2000). Unsuccessful mature applicants and Irish universities: A case study. Fournal of Access and Credit Studies, 2(1), 100-111.

NIACE. (1993). An adult higher education: $A$ vision. Leicester: NIACE.

PARRY, G. \& WAKE, C. (Eds.). (1990). Access and alternative futures for higher education. London: Hodder and Stoughton.

SCHULleR, T. (Ed.). (1991). The future of higher education. Buckingham: Society for Research into Higher Education and Open University Press.

Steering Committee on the Future Development of Higher Education. (1995). Report of the steering committee on the future development of higher education. Dublin: Higher Education Authority.

Tuckett, A. (1990). A higher education system fit for adult learners. In G. PARRY \& C. WAKE (Eds.), Access and alternative futures for higher education (pp. 113-133). London: Hodder and Stoughton.

Universities Act. (1997). Universities Act. Dublin: Stationery Office.

WEIL, S. (1989). Access: Towards education or miseducation? Adults imagine the future. In O. Fulton (Ed.), Access and institutional change (pp. 110-145). Milton Keynes: Society for Research into Higher Education and Open University Press.

WEIL, S. \& MCGILL, I. (Eds.). (1989). A framework for making sense of experiential learning. In S. WeIL \& I. MCGILl (Eds.), Making sense of experiential learning: Diversity in theory and practice (pp. 3-24). Milton Keynes: Society for Research into Higher Education and Open University Press.

WeSt, L. (1996). Beyond fragments: Adults, motivation and higher education-a biographical analysis. London: Taylor \& Francis.

Williamson, B. \& CofField, F. (1997). Repositioning higher education. In F. Coffield \& B. Williamson (Eds.), Repositioning higher education (pp. 116-132). Milton Keynes: Society for Research into Higher Education and Open University Press.

WRight, P. (1989). Putting learning at the centre of higher education. In O. Fulton (Ed.), Access and institutional change (pp. 99-109). Milton Keynes: Society for Research into Higher Education and Open University Press.

YounG, M. (Ed.). (1971). Knowledge and control. London: Collier-Macmillan. 